\title{
Sero-Prevalence and Molecular Detection of Brucellosis among Febrile Patients in West Darfur State, Sudan
}

\author{
Ali Mohamed Badri ${ }^{*}$ and Sameer Ghorashi Mohamed ${ }^{2}$ \\ ${ }^{1}$ Molecular Biology Research Lab, International University of Africa, Khartoum, Sudan \\ ${ }^{2}$ Medical Laboratory Sciences, International University of Africa, Khartoum, Sudan
}

"Corresponding author: Badri AM, Molecular Biology Research Lab, International University of Africa, Khartoum, Sudan, Tel: +249922233425; E-mail: ali.almhasi@gmail.com

Received date: January 15, 2018; Accepted date: January 20, 2018; Published date: January 27, 2018

Copyright: (c 2018 Badri AM, et al. This is an open-access article distributed under the terms of the Creative Commons Attribution License, which permits unrestricted use, distribution, and reproduction in any medium, provided the original author and source are credited.

\begin{abstract}
Brucellosis is a worldwide zoonosis with a high degree of morbidity in humans. It was formerly known as Mediterranean fever, Malta fever or undulant fever. The aim of this study to determine the prevalence of brucellosis among febrile negative malaria patients consume raw milk in West Darfur State, Sudan. In this cross sectional study, one hundred and half blood samples were collected from febrile patients and examined by Rose Bengal (RBPT), ELISA, SAT and PCR methods. The results showed 55 samples were positive by RBPT method, 67 samples were positive by SAT, 72 samples were positive by ELISA and 110 sample positive by nested PCR. Deficiency of awareness of brucellosis with prevailing routine habit of consumption raw milk and close contact with infected animals can function as mean of infection to human beings, molecular methods and could be a useful tool for the detection of Brucella spp.
\end{abstract}

Keywords: Brucella; PCR; ELISA; SAT; RBPT; Febrile patients; Sudan

\section{Introduction}

Brucellosis is a global zoonosis infectious disease [1]. It is caused by a member of genus Brucella that have the ability for persistence in the host cells and replicate, is related with their ability to cause a persistent infection and to inhibition the immunity. Various Brucella species affect sheep, goats, cattle, deer, elk, pigs, dogs and humans [2]. The disease was also reported in camels [3,4] and in marine mammals [5]. Transmission to humans occurs through different routes: the ingestion of unpasteurized milk and dairy products; direct contact with infected animal tissues; or accidental ingestion, inhalation or injection of cultured Brucella. Brucellosis is currently thought to be a possible biological weapon as it is highly contagious and air born transmission of the agent. [6]. Symptoms of brucellosis are not pathognomonic [7]. The disease in animals is characterized by bacteremia followed by localization of the organism in the reticuloendothelial tissues, reproductive organs and sometimes joints. Lesions of the reproductive tract of the pregnant female in cattle, sheep and goats may result in death and abortion of the fetus. Brucella also causes lesions in the male reproductive organs in cattle, sheep, goats and dogs and also bursitis in horses [8]. In human the most common clinical symptoms are fever (78\%), arthralgia (65\%), myalgia (47\%) and back pain (45\%) [9]. As $78 \%$ patients with brucellosis suffers from fever, it is a diagnostic challenge in malaria-endemic areas. Hepatomegaly and splenomegaly are reported in $23 \%$ and $26 \%$ patients, respectively [9]. Lifethreatening focal complications are endocarditis and neurobrucellosis but the overall case fatality is less than $1 \%[10,11]$. Severe complications of brucellosis infection are not rare, with 1 case of endocarditis and 4 neurological cases per 100 patients as reported by Dean et al. [9]. It is also reported by Dean et al. [9] that one in 10 men suffers from epididymo-orchitis. Poor diagnosis and treatment may result in complications like osteoarticular (sacroilitis, spondylitis, peripheral arthritis and osteomyelitis), dermal (erythematous papular lesions, purpura, dermal cysts), genitourinary (orchiepididymitis, glomerulonephritis and renal abscess), respiratory (pleural effusions and pneumonia), cardiovascular (endocarditis), and neurologic disorders (peripheral neuropathies, meningoencephalitis, transient ischemic attacks, psychiatric manifestations and cranial nerve compromise) resembling many other infectious and non-infectious diseases $[10,12]$. The economic and public health impact of brucellosis remains of concern in developing countries [13]. The disease poses a barrier to trade of animals and animal products, an impediment to free animal movement [14].

The diagnosis of human brucellosis is usually based on the isolation of Brucella spp. from blood, tissue specimens, body fluids and bone marrow, the serological tests for the detection of anti-Brucella spp. antibodies and the molecular methods for the detection of Brucella spp. DNA [15]. In countries where brucellosis is enzootic (i.e., present in animal reservoirs), human confirmed cases are based on clinical symptoms associated with positive serology without attempts to isolate Brucella spp. [16]. Serological testing is fast, non-hazardous and more sensitive than culture and therefore preferred in routine clinical practice. The PCR is more sensitive than blood cultures and more specific than serological tests [17]. The analytical sensitivity can be further increased by using real-time PCR assays, which can detect as few as five bacteria per reaction $[18,19]$. Moreover, real-time PCR enables high-throughput screening of clinical samples.

\section{Materials and Methods}

\section{Sample collection}

This was a health facility based descriptive cross-sectional study. A total of 150 blood samples were collected from febrile negative malaria patients consume raw milk in Wester Darfur State during the period 
Page 2 of 4

from August to November 2017. Collected blood samples were centrifuged at $5000 \mathrm{rpm}$ for $5 \mathrm{~min}$ to obtain the serum. The serum was immediately stored at $-20^{\circ} \mathrm{C}$ until used.

\section{Exclusion criteria}

The study excluded Febrile positive malaria patients.

\section{Ethical consideration}

This study was approved by the ethical committee of International University of Africa, Faculty of Medical Laboratory Sciences and verbal consent was obtained from each patient enrolled in this study.

\section{Serological methods}

Rose Bengal plate agglutination: The Rose Bengal plate agglutination test (RBPT) antigen produced by the Central Veterinary Research Laboratories Khartoum, Sudan was used. For this test $25 \mu \mathrm{l}$ of plain serum is dispensed on a white glossy ceramic tile and mixed with an equal volume of RBT antigen. Agglutination was considered as positive reaction, whereas no agglutination was considered as negative for RBPT.

Serum agglutination test (SAT): The SAT antigen was prepared and standardized in Division of Brucella research in Veterinary Research Institute (VRI) Soba, the antigen was diluted 1:120 using phenol saline. According to Buxton et al. The test was read by examining the tubes against a black background with light coming from behind the tubes. A positive reaction is one in which the serum-antigen mixture is clear and agglutinated antigen appears at the bottom of the tube. Gentle shaking does not disrupt the floculi. This is a complete agglutination and is recorded as ++++ . In partial agglutination serum-antigen mixture is partially clear and gentle shaking does not disrupt the floculi, this was recorded as +++ or ++ . Some sedimentation as + and no clearing as negative reaction.

Indirect ELISA IgM antibody: iELISA was performed according to Limet et al. [20] using B. abortus biotype 1 (Weybridge 99) S-LPS as antigen.

\section{Molecular Detection}

\section{DNA extraction}

DNA extraction was done by following SDS and Proteinase K extraction method [21]. $300 \mu \mathrm{l}$ of blood samples were suspended in 1.5 $\mathrm{ml}$ Eppendorf's tube with $1000 \mu \mathrm{l}$ red cell lysis buffer (RCLB), mixed well and centrifuged at $5000 \mathrm{rpm}$ for $10 \mathrm{~min}$, Supernatant was discarded and $300 \mu \mathrm{l}$ of white cell lysis buffer (WCLB) was added, $10 \mu \mathrm{l}$ of $10 \%$ SDS and $10 \mu \mathrm{l}$ of protein's K solution were then added and the mixture was incubated for $1 \mathrm{~h}$ at $65^{\circ} \mathrm{C}$. Then $100 \mu \mathrm{l}$ of $6 \mathrm{M} \mathrm{NaCl}$ was added followed by $200 \mu \mathrm{l}$ of cold chloroform and centrifuged at 11000 rpm for 6 min supernatant containing the DNA was then transferred to a new tube and absolute ethanol was added and centrifuged at 11000 $\mathrm{rpm}$ for $5 \mathrm{~min}$. The supernatant was then discharged and the pellet was washed with $600 \mu \mathrm{l} 70 \%$ ethanol and centrifuged at $6000 \mathrm{rpm}$ for 5 min, the ethanol was discarded and the purified DNA was dissolved in $100 \mu \mathrm{l}$ TE buffer and stored at $-20^{\circ} \mathrm{C}$ until tested by PCR.

Polymerase chain reaction (PCR): PCR was performed and the test was carried out using following primers: forward: 5'-
GACGAACGGAATTTTTCCAATCCC-3' and reverse: 5'TGCCGATCACTTAAGGGCCTTC

AT -3'. Each reaction was performed in total volume of $25 \mu \mathrm{l}$, containing $5 \mu \mathrm{l}$ master mix (Solis Bio dyne master mix), $2 \mu \mathrm{l}$ of primer, $5 \mu \mathrm{l}$ of DNA and $13 \mu \mathrm{l}$ of distilled water. Reactions were performed using PCR machine under the following cycling conditions $110^{\circ} \mathrm{C}$, $95^{\circ} \mathrm{C}$ for $5 \mathrm{~min}$; 35 cycle were $95^{\circ} \mathrm{C}$ for $1 \mathrm{~min}, 65^{\circ} \mathrm{C}$ for $1 \mathrm{~min}, 72^{\circ} \mathrm{C}$ for $1 \mathrm{~min}$ extension at $72^{\circ} \mathrm{C}$ for $7 \mathrm{~min} .5 \mu \mathrm{l}$ of the PCR product was analyzed by gel electrophoresis in $2 \%$ Agarose, and stained with $0.15 \%$ Ethidium bromide and the product was visualized by using UV gel documentation system. The expected size of B. abortus DNA amplicon is $494 \mathrm{bp}$.

\section{Data analysis}

The data were analyzed using the statistical package for the social sciences (SPSS version 20). Cross Tabulation-Chi-square and Kappa values were used to compare the different test.

\section{Results}

Serological testing of the 150 samples found 55 (36.6\%) samples positive by RBT; 67 (44.6\%) samples positive by SAT and 72 (48\%) positive by I-ELISA for presence of antibodies against Brucella, whereas, molecular testing (73.3\%) sample were positive by PCR (Table 1). There were 9 samples that were positive by SAT but negative in RBPT. There were 9 samples that were positive by ELISA, SAT and RBPT but negative in the PCR. While 62 samples that were negative by serological tests were positive in PCR There were 22 SAT and PCR positive samples that were negative in the RBPT and 48 samples were positive in all the test. The agreement between RBPT and PCR (0.34) (Table 2), between SAT and Rose-Bengal (0.83) (Table 3), between IELISA and RBPT (0.71) (Table 4) and between I-ELISA and PCR (0.54) (Table 5).

\begin{tabular}{|l|c|c|c|}
\hline Test & Positive samples & Negative samples & Total \\
\hline Rose-Bengal Test & 55 & 95 & 150 \\
\hline SAT & 67 & 83 & 150 \\
\hline ELISA & 72 & 78 & 150 \\
\hline PCR & 110 & 40 & 150 \\
\hline
\end{tabular}

Table 1: Frequencies of brucellosis among febrile patient in Wester Darfur State, Sudan by using RPBT, SAT, ELISA and PCR.

\begin{tabular}{|l|c|c|c|}
\hline Test & PCR Positive & PCR Negative & Total \\
\hline Rose-Bengal positive & 40 & 15 & 55 \\
\hline Rose-Bengal negative & 65 & 30 & 95 \\
\hline Total & 105 & 45 & 150 \\
\hline
\end{tabular}

Kappa value $=0.34$

Table 2: Cross tabulation of PCR and Rose-Bengal results. 


\begin{tabular}{|l|l|l|l|}
\hline Test & SAT Positive & SAT Negative & Total \\
\hline Rose-Bengal positive & 36 & 9 & 45 \\
\hline Rose-Bengal negative & 42 & 22 & 64 \\
\hline Total & 78 & 31 & 109 \\
\hline Kappa value $=0.83$ & \multicolumn{3}{|l}{} \\
\hline
\end{tabular}

Table 3: Cross tabulation of SAT and Rose-Bengal results.

\begin{tabular}{|l|l|l|l|}
\hline Test & ELISA Positive & ELISA Negative & Total \\
\hline Rose-Bengal positive & 38 & 18 & 56 \\
\hline Rose-Bengal negative & 34 & 37 & 71 \\
\hline Total & 72 & 55 & 127 \\
\hline Kappa value $=0.71$ & & \\
\hline
\end{tabular}

Table 4: Cross tabulation of ELISA and Rose-Bengal results.

\begin{tabular}{|l|l|l|l|}
\hline Test & PCR Positive & PCR Negative & Total \\
\hline ELISA positive & 76 & 13 & 89 \\
\hline ELISA negative & 19 & 18 & 37 \\
\hline Total & 95 & 31 & 126 \\
\hline Kappa value $=0.54$ & \multicolumn{2}{|l}{} \\
\hline
\end{tabular}

Table 5: Cross tabulation of PCR and ELISA results.

\section{Discussion}

The diagnosis of brucellosis remains as one of the most challenging tests of medical knowledge and clinical acumen of the physicians. Brucellosis is diagnosed either by isolation of Brucella organisms in culture or by a combination of serological tests and clinical findings consistent with brucellosis. Isolation of the Brucella organism is the definitive means of diagnosis, but in practice it is difficult due to the early tissue localization and the exacting culture requirements of the organism. In practice, blood cultures are positive in $10-30 \%$ of brucellosis and the remainder is diagnosed serologically. Symptoms and signs of human brucellosis are not specific [22-24]. Isolation of organism in culture or identification of organism by serological and molecular methods for confirming clinical diagnosis is necessary $[25,26]$. The RBPT is usually used for brucellosis screening, its high sensitivity, ease and speed of use, as well as its low cost have made it very popular in hospital emergency departments for the diagnosis of febrile syndromes [27]. However, this test result must also be approved by another test.

\section{Serum agglutination test (SAT)}

The SAT has been used extensively for brucellosis diagnosis and, although simple and cheap to perform, its lack of sensitivity and specificity mean that it should only be used in the absence of alternative techniques. In each set of tests, a positive control serum calibrated against the International Standard for B. abortus antiserum (ISABS) must be included. ELISA is a rapid, sensitive and specific assay providing a profile of immunoglobulin classes in the diagnosis of acute

and chronic brucellosis; therefore, it is useful for mass screening and could be considered the method of choice for the serological diagnosis of the named disease [28]. PCR assay for the diagnosis of human brucellosis, appeared to be a more sensitive technique than microbiological methods, not only for the diagnosis of a first episode of infection, but also for the early detection of relapses [29].

The present study revealed that the overall sero-prevalence of brucellosis in patients with fever in north Darfur state was $36.6 \%$, $44.6 \%, 48 \%$ and 73.3 with RBPT and SAT, ELISA and PCR respectively. Our results also showed that PCR revealed the highest sensitivity in detecting Brucella infection (73.3\%) indicating that most of our patients were at the acute phases of the disease, it also indicates that PCR is probably the method of choice for diagnosis of brucellosis in the feverish patients in endemic areas.

The prevalence of human brucellosis found in this study is slightly higher than reported by Abdelhady R. The prevalence (36\%) based on RBPT in this study was less than that obtained earlier in some herds $(60 \%)$. Clinicians in continue to treat febrile patients for presumptive malaria, resulting in missed opportunities to accurately detect and treat other causes of fever $[30,31]$. The results also highlight the usefulness of PCR as a complementary assay to ELISA, SAT and RBPT as a diagnostic approach in diagnosis of acute brucellosis. The magnitude of human Brucella infection can serve as a barometer of the prevalence of the disease in domestic animals. Eradication of brucellosis in animals is the key to prevention in humans. Nevertheless, public health education assumes an important role in preventing the transmission of brucellosis from animals to humans.

\section{Conclusion}

The risk of spread the disease due to uncontrolled movement of animals, poor hygiene and management conditions and free sale of infected animals in the markets cannot be overlooked. Deficiency of awareness of brucellosis with prevailing routine habit of consumption raw milk and close contact with infected animals can function as mean of infection to human beings. However, detection of pathogen should be used clinical history coupled with combination of two or more tests reduces diagnostic errors. molecular methods and could be a useful tool for the detection of Brucella spp.

\section{Acknowledgments}

We are grateful to prof Mohamed Saeed Elthahir Director Technical Administration and Department of Microbiology, Faculty of Medical Laboratory Sciences, International University of Africa, Khartoum, Sudan.

\section{References}

1. Gul ST Khan A (2007) Epidemiology and epizootology of brucellosis: A review. Pakistan Vet J 27: 145-151.

2. CDC (2002) Public health fact sheet - Brucellosis. Massauchsetts, USA.

3. Abbas B, Agab H (2002) A review of camel brucellosis. Prev Vet Med 55: 47-56.

4. Hegazy AA, Dughaym A, Eknah M, Housawi F, Hatem ME (2004) Studies on mastitis in female camel with special reference to brucellosis. J Camel Sci 1: 96-102.

5. Forbes LB, Nielsen O, Measures L, Ewalt DR (2000) Brucellosis in ringed seals and harp seals from Canada. J Wildl Dis 36: 595-598. 
Citation: Badri AM, Mohamed SG (2018) Sero-Prevalence and Molecular Detection of Brucellosis among Febrile Patients in West Darfur State,

Page 4 of 4

6. Garner G, Saville P, Fediaevsky A (2003) Amanual for the recognition of exotic disease of livestock: A reference guide for animal health staff. Brucellosis (bovine).

7. Leyla G, Kadri G, Umran O (2003) Comparison of polymerase chain reaction and bacteriological culture for the diagnosis of sheep brucellosis using aborted fetus samples. Vet Microbiol 93: 53-61.

8. Gillespie JH, Timoney JF (1981) Hagan and Bruner's microbiology and infectious diseases of domestic animals. Ithaca, Cornell University Press.

9. Dean AS, Crump L, Greter H, Hattendorf J, Schelling E, et al. (2012) Clinical manifestations of human brucellosis: A systematic review and meta-analysis. PLoS Negl Trop Dis 6: e1929.

10. Godfroid J, Scholz H, Barbier T, Nicolas C, Wattiau P, et al. (2011) Brucellosis at the animal/ecosystem/human interface at the beginning of the 21st century. Prev Vet Med 102: 118-131.

11. Olsen SC, Palmer MV (2014) Advancement of knowledge of brucella over the past 50 years. Vet Pathol 51: 1076-1089.

12. Franco MP, Mulder M, Gilman RH, Smits HL (2007) Human brucellosis Lancet Infect Dis 7: 775-786.

13. Roth F, Zinsstag J, Orkhon D, Chimed-Ochir G, Hutton G (2003) Human health benefits from livestock vaccination for brucellosis: Case study. Bull World Health Organ 81: 867-876.

14. Zinsstag J, Schelling E, Solera X, Blasco J, Moriyon I (2011) Brucellosis Oxford Textbook of Zoonoses, pp: 54-64.

15. Sakran W, Chazan B, Koren A (2006) Brucellosis: Clinical presentation diagnosis, complications and therapeutic options. Harefuah 145: 836-840.

16. CDC (1997) Case definitions for infectious conditions under public health surveillance. Morb Mort Wkly Rep MMWR 46:1-55.

17. Al Dahouk S, Sprague LD, Neubauer H (2013) New developments in the diagnostic procedures for zoonotic brucellosis in humans. Rev Sci Tech 32: $177-188$.

18. Navarro E, Segura JC, Castaño MJ, Solera J (2006) Use of real-time quantitative polymerase chain reaction to monitor the evolution of Brucella melitensis DNA load during therapy and post-therapy follow-up in patients with brucellosis. Clin Infect Dis 42: 1266-1273.

19. Al Dahouk S, Nöckler K (2011) Implications of laboratory diagnosis on brucellosis therapy. Expert Rev Anti Infect Ther 9: 833-845.

20. Limet J, Kerkhofs P, Wijffels R, Dekeyser P (1988) Serological diagnosis of bovine brucellosis by ELISA. Ann Med Vet 132: 565-575.
21. Nishiguchi MK, DeSalle R Giribet G, Wheeler WC (2002) DNA isolation procedures techniques in molecular systematics and evolution. pp: 247-287.

22. Gamazo C, Vitas AI, GoniI L, Diaz R, Morrion I (1993) Factor affecting detection of Brucella melitensis by BACTEC NR730, a non-radiometric system for hemocultures. J Clin Microbiol 31: 3200-3203.

23. Mantur BG, Amarnath SK, Shinde RS (2007) Review of clinical and laboratory features of human brucellosis. Indian J Med Microbiol 25: 188-202.

24. Richtzenhain LJ, Cortez A, Heinemann MB, Soares RM, Sakamoto SM, et al. (2002) A multiplex PCR for the detection of Brucella spp. and Leptospira spp. DNA from aborted bovine fetuses. Vet Microbiol 87: 139-147.

25. Leal-Klevezas DS, Martinez-Vazquez IO, Lopez-Merino A, MartinezSoriano JP (1995) Single-step PCR for detection of Brucella spp. from blood and milk of infected animals. J Clin Microbiol 33: 3087-3090.

26. Omer MM, Musa MT, Bakhiet MR, Perrett L (2010) Brucellosis in camels, cattle and humans: Associations and evaluation of serological tests used for diagnosis of disease in certain nomadic localities in Sudan. Rev Sci Tech 29: 663-669.

27. Ruiz-Mesa JD, Sanchez-Gonzalez J, Reguera JM, Martin L, Lopez Palmero S, et al. (2005) Rose Bengal test: Diagnostic yield and use for the rapid diagnosis of human brucellosis in emergency departments in endemic areas. Clin Microbiol Infect 11: 221-225.

28. Araj GF, Lulu HR, Khateeb MI, Saadan MH, Shakir RA (1988) ELISA versus routine tests in the diagnosis of patients with systemic and neurobrucellosis. APMIS 96: 171-176.

29. Briones-Lara E, Palacios-Saucedo GC, Martínez-Vázquez IO, MoralesLoredo A, Bilbao-Chávez LP (2007) Response to the treatment of brucellosis among children. Rev Med Inst Mex Seguro Soc 45: 615-622.

30. Young EJ (1995) An overview of human brucellosis. Clin Infect Dis 21: 283-289.

31. Zerva L, Bourantas K, Mitka S, Kansouzidou A, Legakis NJ (2001) Serum is the preferred clinical specimen for diagnosis of human brucellosis by PCR. J Clin Microbiol 39: 1661-1664. 